\title{
SOCIOLINGUISTIC ROUTINES IN SOCIAL INTERACTION IN BATAK TOBA LANGUAGE
}

\author{
Esron Ambarita \\ esronambarita@gmail.com \\ Faculty of Letters \\ University of Methodist Indonesia
}

\begin{abstract}
This research deals with the investigation of sociolinguistic routines in social interaction in Batak Toba language. The major issues in this descriptive microlinguistic study were the application of sociolinguistic routines in aspects of social interaction where sociolinguistic routines were found. Besides, this research also found the way sociolinguistic routines in social interaction in Batak Toba language are expressed. The results show that sociolinguistic routines in social interaction in Batak Toba language are found in many aspects, they are: (1) greetings, (2) self introduction, (3) offer, (4) giving, (5) apologizing, (6) permissions, (7) invitations, (8) reply, (9) requests, (10) regrets, and (11) leave taking. As far as the research had been done, the way sociolinguistic routines in Batak Toba language are expressed by using terms of kinship such as amang, inang, tulang, nantulang, amang boru, namboru, ito, lae, hela, parumaen, amang bao, inang bao, bere, paraman, appara, etc. Sociolinguistically, there is not any fixed sociolinguistic routines for each of the routines above because they depend on some social factors, such as, terms of kinship, age, gender, and familiarity.
\end{abstract}

Key words: sociolinguistics, routines, social interaction 


\section{INTRODUCTION}

People use language to communicate with others. Therefore, the role of language is very important in our life in doing our social activities. The use of language is often determined by norms in the society where it is used. That is to say that the diction used in conversation depends on who talks to whom (Hudson, 1980: 116-119). Conversation is not a structural product in the same way that a sentence is - it is rather the outcome of the interaction of two or more independent, goal-directed individuals, with often divergent interests (Levinson, 1985: 294).

In other words, the norms in a society rule the speakers to select one of the communication ways in order to convey their intention (Gumperz and Hymes, 1972: 54). There must be norms which may vary sub-group and social setting (Wardhaugh, 1964: 116). In other words, every sub-group or tribe has its own norms in communication. The speakers do not speak as they like. For example, in Batak Toba language the way speakers communicate with older people is different from that with younger ones. The way they do their communication depends on their kinship. Therefore, in Batak Toba language the sets of social norms still exist to propose the terms of kinships. In Batak Toba language, some one can be considered as polite or impolite from the way he speaks.

The objectives of this research are to find out: (1) the aspects of social interaction where sociolinguistic routines are found and (2) the way sociolinguistic routines in social interaction in Batak Toba language are expressed.

\section{REVIEW OF LITERATURE}

\section{a. Language and Social Interaction}

People use language to cooperate and to interact to person in society. We talk to our friends, our families and our associates by using language. Without language people can, not express their opinions, ideas, and their minds. The study of relationship between language and society is called sociolinguistics. According to Hudson (1980: 4) sociolinguistics is the study of language in relation to society.

From the defenition above, we see that sociolinguistics concerns with investigating relationship between language and society to obtain the goal of a better understanding of the function of language as a means of communication. Language that 
we use in our everyday life is not only specified by linguistic factors but also social factors (Wardhaugh, 1964: 48). He also states that social factors such as education, social status, age, sex or gender may influence or determine the language use. On closer examination, there are few, if any, context-independent gender differences in language (Romaine, 2000: 103). Furthermore, language is also influenced by situational factors such as who is the speaker, who is the addressee, where the utterance takes place, when and how it takes place.

According to Bloomfield (1933: 17) there are three kinds of language in our daily life, they are:

a. Spoken language; that is language which is expressed directly by a speaker to a listener.

b. Written language; that is language which uses writing as a medium of expressing desire from a writer to the reader.

c. Gesture language or silent language; that is a language which uses body movements or things such as hands, eyes, lights, etc.

\section{b. Language Style}

According to Joos (in Nababan, 1984: 22) there are five styles of language based on its formality, they are:

a. Frozen style, This style of language is most found in ceremonial occasions. This form can also be found in, documents, institutions and i.-m, other kinds of history documents.

b. Formal style. This style is used when the speaker, wants to inform something to the listener. It is usually used in a very formal speech, public lectures, etc.

c. Consultatives style. This style is usually used in the forms of communication in a company. This style is less formal. Consultatives style are also used in group discussion, in the hospital, etc.

d. Casual style, This style is used among close friends, in sports, in travelling, etc.

e. Intimately style. This style is usually used by the members of the family and among close friends 
Accroding to Hudson (1980: 48) the term style is widely used in sociolinguistics to refer to varieties according to use. A person might utter one sentence in different ways depends on where he is, with whom he is speaking to, etc. According to Peccei (1999: 4) in his book Pragmatics linguists often make the distinction between a sentence and an utterance for two reasons, they are, first pragmatics analyses language in use and many of the utterances we use do not consist of full sentences yet understable in context. For example:

$$
\begin{array}{ll}
\text { Jane } & \text { : Coffee: } \\
\text { Steve } & \text { : Sure! } \\
\text { Jane } & \text { : White? } \\
\text { Steve } & \text { : Black. }
\end{array}
$$

Second, while we can talk about the two sentences Cats drink cream and Cats drink cream as being exactly the same, we cannot really say this about utterances because each utterance is unique even created at a particular point in time for a particular purpose. It means that one will use one of the language styles above. This idea is also supported by Montgomery (1986: 106) states that the form of the social interaction is reflected in the choice of personal pronouns used by speakers of a language. In this context, the personal pronoun can be considered as terms of kinship.

Argyle (1968: 26) states by having language, human beings can communicate their culture to one another and to the next generation. In other words, where there is a language there is a culture there (Nababan, 1984: 50).

\section{c. Social Interaction}

Social interaction cannot be separated form human life. It is a pattern of interaction among the society members to thread communication, not only in verbal communication but also in non verbal communication in their daily life. The term non verbal communication or body language as it is also commonly known, refers to the bodily movements which accompany speech and which add meaning to the interaction (Thompson: 2003: 97). Speech events, on the other hand, are both communicative and governed by rules for the use of speech (Fasold: 1990: 42).

However, social interaction is embodied in cultural rules and norms, and it is thought by the parents to younger generation indirectly (Argyle, 1968: 25). One of the simple examples of the social interaction among society members are greeting by using 
special expression in their own language. Other examples are hugging and shaking hands. Moreover, according to Argyle (1968: 430) there are three main channels used in human social interaction, they are hearing, vision, and the ways in which these are linked.

\section{d. Sociolinguistic Routines}

Talking about sociolinguistic routines, there is a proverb in bahasa Indonesia saying lain lubuk, lain ikannya. For this discussion, the proverb can be interpreted as different place, different language. That is to say, every language has their own ways to express ideas in social interaction. These kinds of expression are usually called routines. In other words, According to Richard (1978: 65) routines are conventionalized speech and generally they are segments of language made up of several words which are utterred together and used as if they were single item. He also states that routines are usually used in a conversation in our daily life. Some kinds of expressions which are called routines are greeting, apologizing, thanking, offering, inviting, etc (ErvinTripp, 1973: 243).

\section{METHOD OF RESEARCH}

The study was done by using qualitative design. It is a kind of research to explore Batak Toba language phenomena naturally on the topic under discussion. The data of this research were collected from two sources, theybare:

a. Documentary study

The writer looked up data about sociolingusitic routines in social interaction in Batak Toba language from written conversation forms in Batak Toba language.

b. Observation

The writer directly observe the participants in the field as the object of this research. Therefore, the data collected through recording are based on the natural utterances produced by the participants.

\section{FINDINGS AND DISCUSSIONS}

This subchapter discusses findings and discussions of the research dealing with sociolinguistic routines in social interaction in Batak Toba language. The results show 
that sociolinguistic routines in social interaction in Batak Toba language are found in many aspects of communication. They are explained in the following parts.

\subsection{Greeting}

Greeting is the first word used in accosting somebody or writing to somebody for expressing respect and relationship. Every community has its own special ways of greeting. In Batak Toba community it usually occurs in social meeting, feast, accidental meeting, or when some friends or relatives are visiting their homes and their villages. Greeting is usually a token of good relationship between a speaker and listener. There are many ways to show respect to other. For instance, we have to know first the term of kinship that exists in Batak Toba.

For example:

A: Horas amang, boha kabar amang?

Greeting TK how news father.

'Horas father in law, how are you?'

TK $=$ Term of Kinship

$\operatorname{Pr}=$ Preposition

B: Horas ma tutu, kabar sehat do amang hela.

Greeting, Part. true news health Part. TK.

'Horas, I am fine son in law.'

Horas in Batak Toba language is a very famous word. Literally, horas means long life. The word horas is even used not only by Batak Toba language speakers but also by people who do not speak Batak Toba language where they meet Batak Toba people or when visitors come to Batak land 'Tano Batak'. In Batak Toba language, the word amang has more than one meaning. The word amang as in Horas amang means 'father in law'. We can draw the meaning from the context of their conversation, where speaker B uses the word amang hela in his reply. In other words, the son in law greets his father in law in the conversation. In Batak Toba language, the word horas is a very frequent routine used in greeting among speakers who thread communication.

\subsection{Self Introduction}

Besides greetings, sociolinguistic routines in Batak Toba language is also found in self introduction. According to Lee (1983: 147) self introduction 
is the expression used by somebody to introduce himself to someone else. For Batak Toba people, this kind of expression often occurs in the situation if two or more persons meet accidentally and they do not know each other.

In Batak Toba, for example, self introduction can be done as in the following.

A: Horas ito, marsitandaan jo hita ito, boru aha ito? Greeting TK introduce us TK, family name (for female) what TK 'Horas my sister, let's introduce our selves, what's your family name?'

B: Boru Sitanggang do au ito.

Family name (for female) Sitanggang Ex me TK. [Ex = Extensifier $]$ 'My family name is boru Sitanggang.'

When Batak Toba people are introducing them selves, it is a custom for them to shake hands strictly and a bit longer while they are extending shorter conversation. In addition, for adult and married Batak Toba people they never introduce them selves by saying name. On the other hand, they just say their family name.

Sometimes, male Batak Toba person introduce themselves by saying his eldest child with introductory phrase ama $n i$ 'the father of'.

For example:

Ama ni Tiurlan do pang- goar -anhu

TK Tiurlan is Prep. name my. [Prep. =Preposoition]

'My nick name is ama ni Tiurlan'.

For female married Batak Toba person, the term of kinship used is na $i$ for example:

Na i Jatorang do pang- goar -anhu.

$T K$ Jatorang is Prep. name my.

'Nai Jatorang is my nick name.'

Further, a person who has already got grandchild or grandchildren will introduce themselves by saying introductory phrase oтри ... 'grand father of' or 'grand morther 
of'. The name of the grandchild added to the word ompu is taken from the name's of the eldest child of the son's side.

For example: Ompu Parlindungan do au.

TK Parlindungan is me.

My nick name is Ompu Parlindungan.

For Batak Toba people, the title ompu is considered honourable. That is why, to have nick name отри is a waited call for persons who are already old whose children already got married.

\subsection{Offering}

The other kind of sociolinguistic routines in Batak Toba language is offering. It is the action of offering or giving something to someone else. In Batak Toba language, offering may occur in serving meals to guests. For example:

$\mathrm{A}: \mathrm{Si}$ allang na tupa ma hita ate. $A r$. eat which available Part. we let's. $(A r .=$ Article; Part $=$ Particle $)$ 'Let's enjoy this meal.'

B: $\mathrm{Na}$ uli. Maulite ma di hamu. Which beautiful. Thanks Part. to you. 'Alright. Thank you.'

Offering also occurs in wedding party. In this party, the parents of the newly married couple come to meet their guests when they are enjoying their meal in the party. In this occasion the parents of the newly married couple will offer their guests to enjeoy the meal by saying:

Godang-godang allang hamu ate.

Much eat eat please.

'Please enjoy yourself.'

\subsection{Giving.}

Giving is an act of handing something to another person without payment or exchange. In Batak Toba culture there is a term mamiring $i$. Mamiring is the action of giving food to the neighbour, especially when the host has guests who bring food to 
their home. Some of the food will be given to the neighbour. In other occasion, when the neighbour has guests with food, the neighbour will do the same thing as well. This is a very good tradition in Batak Toba culture. The conversation can be seen as in the following:

Adong nion saotik sipanganon diboan tondong -ta sian huta. There is here a little food brought family our from village. 'Here is a little food brought by our family from the village.'

Las ma roha muna, allang hamu na ma ate.

Happy Par. heart your, eat you please.

'Please enjoy it.'

In Batak Toba culture there is a proverb saying hansit tangan mulak mangido, hansitan do mulak mangalean. It means in case we ask for something from someone, we will feel hurt if the person rejects what we want. However, we will feel hurt more and more when we give something to someone and the person push down what we give to him. In the data above, for example, usually the neighbour will accept the food if their relation runs well. However, if the neighbour reject the food, their relation will be worse.

\subsection{Apologizing}

Apologizing is asking for an exuse to someone because we feel that we do something wrong. According to Lee (1973: 15 ) there are some circumstances in which apologizing can be done, they are:

a. When someone makes a momentary mistake physically. For example, when someone bumb or trip over somebody's feet, it is a good way to ask for pardon to the person. In Batak Toba language, this exuse can be expressed by saying:

Minta maaf jo bah, dang sangaja au.

Ask for exuse first Exc. not attentionally me. [Exc. = Exclamation] 'I am sorry, I don't do it purposely.'

b. When someone damages a valuable object. In Batak Toba language when someone damages or knocks other's valuable object, they usually say:

Agoi amang! Lomo -m ma, sadia pe nim -mu, dangdangan hu nama i. Ex. like you please how much say you pay I will that. 
'Agoi amang! It's up to you, how much you say, I will pay for it.'

c. When arriving late. When Batak Toba people come late to an appoinment, for example, the following expression is usually mentioned.

Nunga tar- paima ra hamu ate?

Have Pas. wait may be you yes?

'You have been waiting for so long, haven't you?'

d. When someone fail to understand what somebody is saying. In Batak Toba language, when someone fail to understand what somebody is saying, to ask for an exuse they usually say.

Santabi jolo amang boru, aha di- dok hamu nangkin? Dang tangkas hu bege. 'Excuse before, TK what Pas. say you just now? Not clear I hear. 'I beg your pardon amang boru, what did you say just now. I didn't hear clearly.'

e. When causing someone to loose something or taking other possession without permission.

In Batak Toba culture, there is a tradition to take someone's possession not very valuable without permission from the owner because the owner of the thing wanted is not on the place. For instance, when a family is cooking fish, and she needs sour for the meal. It is impossible for her to go to the market because it is very far. As a short cut, she will take her neighbour's sour from the sour tree behind her neighbour's house. As a tradition, when Batak Toba people cook fish, especially sea fish or gold fish, they usually cook it with sour. After her neighbour comes, the woman who already took the sour will express her apology to her neighbour. The following is one expression to show the apology.

Sotung muruk ho eda, hu buat nakkin sabiji asom -mu. Mangaloppa ikkan ahu. Don't angry you TK I take just now one sour you. Cook fish I. 'Please don't get angry with me eda, I took one of your sour. I cook fish. 
f. When we unintentionally say something unclear. In Batak Toba language, when we want to clarify something which is not clear, it is said:

Santabi jolo namboru, dang songon i hu -dok. Excuse before $T K$ not like that I say.

'Excuse me namboru I didn't say that.'

\subsection{Permission}

In Batak Toba tradition, one of the circumstances in which permission is required is when someone wants to pass by other person especially older persons. This kind of permission is much done when Batak Toba people are doing partangiangan 'prayer' or making meeting or doing gathering in one house. Usually Batak Toba people sit in the form of cirle on mats in doing the activities above. In this situation, when one of the persons wants to go out, for example, he needs to make permission when he is passing by those persons. In Batak Toba culture, it is impolite to pass by older persons without permission. The frequent permission used by Batak Toba people in such situation is by saying:

Santabi jolo amang, inang, naeng mamolus jolo ahu.

Excuse before $T K \quad T K$ will pass by before I.

Excuse me amang 'sir', inang 'madam', I will pass by.'

\subsection{Invitation}

An invitation is a request to someone to come to a party. A very common invitation done by Batak Toba people is when there is an event mangadati 'celebrating big wedding party'. The followings are some examples of oral invitation in Batak Toba language:

Horas ito, ro hami manggokhon, ima na naeng manjalo tuhor ni boru hita. Greeting,TKcome we invite, that is which will receive buy of daughter us. 'Horas ito, we come to invite you to the wedding party of our daughter.'

In Batak Toba culture, there is a tradition to invite the neighbour to enjoy the meal brought by the host's family together. The common oral invitation for this situation is: 
A: Beta hamu mangan tu jabu -tta, adong saotik sipanganon diboan iboto-tta. Let's you eat to house our, there is a little food brought sister our.

'Please come and enjoy food in our house, our sister is coming and bringing food.'

This expression is usually replied directly by saying:

B: $\mathrm{Na}$ uli, ro pe hami.

Which nice, come also we.

'Yes, we will come.'

\subsection{Reply}

Batak Toba people are very familiar with expressing deep respect to somebody else who have come to their party or who have given help. For this situation, Batak Toba people usually say:

Mauliate godang ma di haroro muna da.

Thanks a lot Part. in coming you Part.

'Thank you very much for your coming.'

\subsection{Request}

Request is done because the speaker wants someone to do a favour for him. In other words, request is an action to ask for help from somebody. Request often includes a polite word, such as please (Lee, 1983: 97). More over, Lee states that there are many types of utterance that can be interpreted as requests in particular contexts as in the following:

a. When a speaker requests someone to do something or get something done. In Batak Toba language, this intention can be expressed by saying one of the following utterances:

Santabi tulang, pa geser hamu jolo saotik.

Excuse TK Part. move you before a bit.

'Excuse me uncle, would you move a bit please.'

In Batak Toba language, this is a very polite form of request. This kind of utterance is usually headed to someone that the speaker respects very much, or headed to someone who is not familiar with the speaker or older than the speaker. The kind of 
utterances of request which is usually headed to someone of the same age is as in the following.

Geser jolo saotik bah.

Move before a bit Exc.

'Please move a bit.'

The form of request headed to someone younger can be expressed as follows:

Geser -hon jolo saotik.

Move Suf. before a bit. [Suf. = Suffix]

'Move a bit.'

b. When a speaker needs a help. In this situation. For this context,

Batak Toba people usually say:

Santabi lae, urupi hamu jo marhobas di ulaon -ta marsogot ate.

Excuse $T K$, help you before serve in party. our tomorrow please.

'Excuse me lae, would you help serving quests in our party tomorrow?'

c. When a speaker needs infromation. In Batak Toba language, when we need information we say:

Manukkun jo omppung doli, nga sadia umur -mu tahe?

Ask before $T K, \quad$ already how age your right?

'May I ask you grandfather, how old are you now?'

\subsection{Regrets}

Regret is defined as the feeling of sadness at the loss of something, or of annoyance or disappointment because something has or has not been done (Hornby, 1987:710). In Batak Toba language regret can expressed by saying.

Agoi amang, boha nama ujung ni par- sikkola- an mi.

Exc. TK, how Part. point of Part. school Suf. your.

'Agoi amang, how is your study going to be?

\subsection{Leave Taking}

Leave taking is a way of expressing utterance for leaving from one place (Lee, 1983: 128). In English, for example, we say goodbye to express leave taking both for person who leaves and for person who stays. 
In other words, in English the expression goodbye will be replied by the same word goodbye. The other chioce to express leave taking in English is see you later, see you tomorrow, till we meet again, etc.

In bahasa Indonesia we say selamat jalan to person who leaves and selamat tinggal for person who stays. However, in Batak Toba language there is not any special expression to express leave taking. Usually the following expressions are use to express leave taking in Batak Toba language.

Marhehe na uli ma jolo hami amang. Horas ma.

Raise which nice before us TK. GR. Part.

Goodbye amang, we are leaving. Horas.

Borhat ma jolo hami inang, horas ma hita sude.

Go Part. before us TK, GR. Part. us all.

'Goodbye inang. Horas (long life) for all of us.'

Lao ma jolo hami namboru. Sehat-sehat sude da.

Go Part.before us TK. Healthy all please.

'See you later namboru. We hope that we are always healthy.'

\section{CONCLUSIONS}

Based on the analysis of sociolinguistic routines in Batak Toba language above some conclusions can be drawn, they are, sociolingusitic routines in Batak Toba language are found in many aspects of social interaction, they are: (1) greetings, (2) self introduction, (3) offer, (4) giving, (5) pologizing, (6) permissions, (7) invitations, (8) reply, (9) requests, (10) regrets, and (11) leave taking.

Sociolinguistically, there is not any fixed sociolinguistic routines for each of the routines above because they depend on some social factors, such as, terms of kinship, age, gender, and familiarity. Some of the terms of kinship in Batak Toba language are amang, inang, tulang, nantulang, amang boru, namboru, ito, lae, hela, parumaen, amang bao, inang bao, bere, paraman, appara, etc. 


\section{REFERENCES}

Argyle, Ichael. 1968. Social Interaction. London: Mexhuen and Company Limited. Bloomfield, Leonard. 1933. Language. New York: Holt, Rinehart and Winston Inc. Blundell, John. et al. 1982. Function in English. Oxford: Oxford University Press.

Crystal, David. 1983. A Dictionary of Linguistics and Phonetics. London: The Trinity Press.

Fasold, Ralph. 1990. The Sociolinguistics of Language. Cambridge. Basil Blackwell Inc.

Gumperz, J.J and Dell Hymes. 1972. Direction in Sociolinguistics. New York: Holt, Rinehart and Winston Inc.

Hornby, AS. Oxford Advanced Learner's Dictionary of Current English. Oxford: Oxford University Press.

Hudson, R. 1980. Sociolinguistics. New York: Cambridge University Press.

Ihromi, T.O. 1986. Masyarakat dan Hukum Adat Batak Toba. Jakarta: Pustaka Azet.

Lee, William.R. 1983. A Study Dictionary of Social English. New York: Pergamon Press.

Levinson, Stephen C. 1985. Pragmatics.

Montgomery, Martin. 1986. An Introduction to Language and Society. New York: Cambridge University Press.

Nababan, P.W.J. 1984. Sosiolinguistik Suatu Pengantar. Jakarta: PT. Gramedia. 1987. Ilmu Pragmatik (Teori dan Penerapannva). Jakarta: Departemen Pendidikan dan Kebudayaan.

Pateda, Mansoer. 1990. Sosiolinguistik. Bandung: Penerbit Angkasa.

Peccei. 1999. Pragmatics. New York: TJ International Ltd.

Romaine, Suzanne. 2000. Language in Society: An Introduction to Sociolinguistics. New York: Oxford University Press.

Thompson, Neil. 2003. Communication and Language. London: Palgrave Macmillan. 